\title{
Prevalence, antimicrobial susceptibility, and molecular characterization of Staphylococcus aureus isolated from dairy herds in northern China
}

\author{
Huimin Liu, ${ }^{\dagger}{ }^{1}$ Songli Li, ${ }^{*}{ }^{1}$ Lu Meng, ${ }^{*}{ }^{1}$ Lei Dong, ${ }^{*} \dagger$ Shengguo Zhao, ${ }^{*} \dagger$ Xinyi Lan, ${ }^{\dagger} \dagger$ Jiaqi Wang, ${ }^{*} \dagger$ \\ and Nan Zheng* $\dagger^{2}$ \\ *Ministry of Agriculture Laboratory of Quality and Safety Risk Assessment for Dairy Products (Beijing), Institute of Animal Science, Chinese \\ Academy of Agricultural Sciences, Beijing 100193, P. R. China \\ †Ministry of Agriculture-Milk and Dairy Product Inspection Center (Beijing), Beijing 100193, P. R. China
}

\begin{abstract}
Staphylococcus aureus is one of the main pathogens involved in dairy cow mastitis. Monitoring of antibiotic use would prove useful to assess the risk of Staph. aureus in raw milk. The objective of this work was to investigate the prevalence of Staph. aureus strains isolated from raw milk in northern China, and to characterize antimicrobial susceptibility of these strains and their key virulence genes. In total, 195 raw milk samples were collected from 195 dairy farms located in 4 cities of northern China from May to September 2015. Out of 195 samples, $54(27.7 \%)$ were positive for Staph. aureus. Among these 54 samples, 54 strains of Staph. aureus were isolated, and 16 strains were identified as methicillin-resistant Staph. aureus. The strains exhibited high percentages of resistance to penicillin G (85.2\%), ampicillin (79.6\%), and erythromycin (46.3\%). Moreover, $72 \%$ of the strains showed resistance to more than one antimicrobial agent. Overall, $63 \%$ of penicillin-resistant strains possessed the bla $Z$ gene, and $60 \%$ of the erythromycin-resistant strains possessed $\operatorname{erm}(\mathrm{A}), \operatorname{erm}(\mathrm{B}), \operatorname{erm}(\mathrm{C}), \operatorname{msr}(\mathrm{A}), \operatorname{or} \operatorname{msr}(\mathrm{B})$ genes with 8 different gene patterns. All isolates resistant to gentamicin, kanamycin, and oxacillin carried the aac6'-aph2", ant(4')-Ia, and mecA genes, respectively. Two tet(M)-positive isolates carried specific genes of the Tn $916-\operatorname{Tn} 1545$ transposon. The most predominant virulence genes were sec, sea, and pvl, which encode staphylococcal enterotoxins (sec and sea) and PantonValentine leukocidin, respectively. Thirty-two isolates $(59.2 \%)$ harbored one or more virulence genes. The majority of Staph. aureus strains were multidrug resistant and carried multiple virulence genes, which may pose a risk to public health. Our data indicated that
\end{abstract}

Received June 21, 2017.

Accepted July 20, 2017.

${ }^{1}$ These authors contributed equally.

${ }^{2}$ Corresponding author: zhengnan_1980@126.com antimicrobial resistance of Staph. aureus was prevalent in dairy herds in northern China, and that antibiotics, especially penicillin $\mathrm{G}$ and ampicillin, to treat mastitis caused by Staph. aureus should be used with caution in northern China.

Key words: antimicrobial resistance, enterotoxins, northern China, raw milk, Staphylococcus aureus

\section{INTRODUCTION}

Staphylococcus aureus is one of the main pathogens involved in dairy cow and goat mastitis worldwide, and it is an important opportunistic pathogen in raw milk (Cavicchioli et al., 2015; Wang et al., 2016). Staphylococcus aureus IMI results in significant economic losses due to reduced milk production and poor milk quality (Stapels et al., 2014), and Staph. aureus infections are related to the expression of virulence factors. Many virulence factors have been found in Staph. aureus isolated from bovine mastitis, including toxic shock syndrome toxin-1 (TSST-1), enterotoxins, enterotoxin-like exfoliative toxin, and Panton-Valentine leukocidin (Kot et al., 2016; Wang et al., 2016). These virulence factors are highly stable to heat or proteolytic enzymes and help bacteria to survive and multiply in the mammary gland (de Freitas Guimarães et al., 2013).

Antimicrobial therapy is an important tool in mastitis control programs, but Staph. aureus responds poorly to therapy with antimicrobial agents (Gomes and Henriques, 2016). Staphylococcus aureus is a pathogen with a remarkable ability to withstand antimicrobial agents and evade the human immune system. By recognizing the resistance mechanisms of Staph. aureus, effective measures in mastitis control programs can be established. Intrinsic resistance and acquired resistance have been shown to contribute to the ability of Staph. aureus to survive specific antimicrobial stress (Baym et al., 2016). It possesses numerous intrinsic factors that limit the effectiveness of specific antimicrobial agents (Rajagopal et al., 2016) and can develop acquired resistance to many other antimicrobial agents by carrying various 
resistance traits on plasmids or transposons (ChajeckaWierzchowska et al., 2015). Acquired antimicrobial resistance has a transmission potential to humans (Ruegg et al., 2015). Therefore, monitoring antimicrobial resistance in Staph. aureus from raw milk is very important in order to predict the rate and type of antimicrobial resistance development and to make decisions regarding antibiotic treatments of animals from a food safety standpoint.

Studies of antimicrobial resistance and virulence traits in Staph. aureus have been performed in milk of bovines with mastitis in several countries, including Turkey, Brazil, Iran, and India, as well as the mideast of China (Gundogan and Avci, 2014; Cavicchioli et al., 2015; Jamali et al., 2015; Mistry et al., 2016; Zhang et al., 2016). However, reports on the incidence of antimicrobial resistance of Staph. aureus from raw milk in dairy herds in northern China are very limited. Continuous monitoring of antimicrobial resistance and virulence profiles of Staph. aureus could be useful to assess the risk of Staph. aureus in raw milk in northern China. Therefore, the objective of this work was to investigate the prevalence of Staph. aureus strains isolated from dairy herds in northern China from May to September 2015, and to characterize these strains by antimicrobial susceptibility and key virulence genes.

\section{MATERIALS AND METHODS}

\section{Collection of Samples}

A total of 195 raw milk samples were collected from 195 dairy farms located in major dairy-production cities of northern China (herd size $\geq 300$, milking frequency 2-3 times per day, no clinical mastitis) from May to September 2015 (average daily temperature $>20^{\circ} \mathrm{C}$ ). We collected 75 samples from Hohhot, 50 from Beijing, 40 from Harbin, and 30 from Jinan (Figure 1). All samples were collected from the milk tank, transferred into sterile bottles, and transported immediately to laboratory at $4^{\circ} \mathrm{C}$ for bacteriological analysis.

\section{Isolation and Identification of Staph. aureus}

For isolation and detection of Staph. aureus, each sample $(10 \mathrm{~mL})$ was added to $90 \mathrm{~mL}$ of sterile peptone water and homogenized. The samples were placed onto Baird-Parker agar supplemented with 5\% egg yolk and

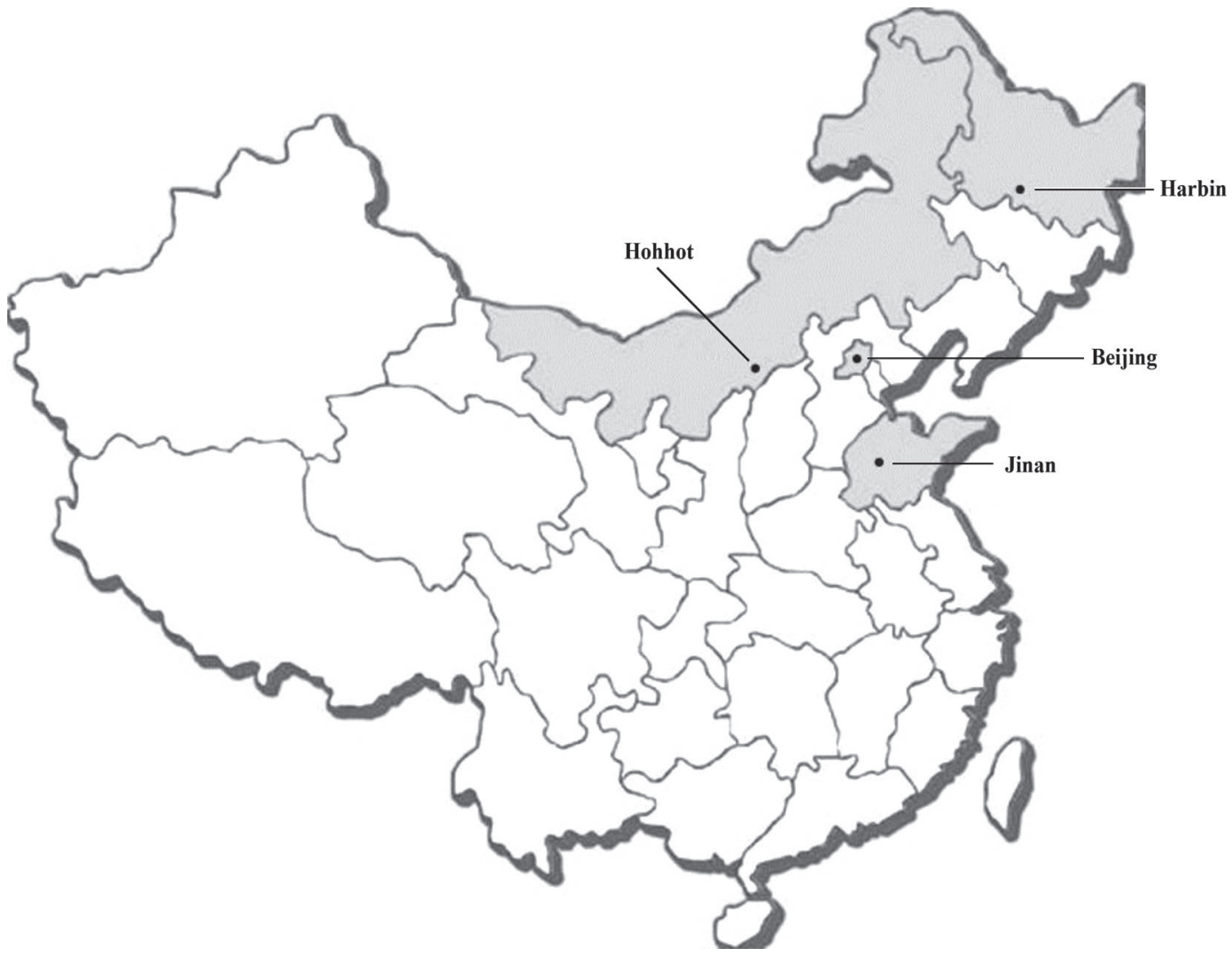

Figure 1. Map of sampling locations. The 4 shaded regions are the main dairy-producing areas in northern China. In total, 75 samples were collected from Hohhot, 50 from Beijing, 40 from Harbin, and 30 from Jinan. 
tellurite (Beijing Land Bridge Technology Ltd., Beijing, China). The plates were incubated for 24 to $48 \mathrm{~h}$ at $37^{\circ} \mathrm{C}$. Colonies with typical black appearance and surrounded by a clear zone were enumerated as Staph. aureus.

\section{Molecular Characterization of Staph. aureus}

Presumptive colonies were confirmed by PCR detection (Bio-Rad S1000, Bio-Rad Laboratories, Hercules, CA) of the Staph. aureus-specific thermonuclease gene (nuc; Supplemental Table S1, https://doi.org/10.3168/ jds.2017-13370). All isolates were stored at $-80^{\circ} \mathrm{C}$ until use.

Genomic DNA of the Staph. aureus isolates was extracted using the InstaGene Matrix DNA extraction kit (Bio-Rad Laboratories) following the manufacturer's instructions. The PCR reactions were performed using the EmeraldAmp Max PCR Master Mix kit (Takara, Dalian, China) and followed the manufacturer's instructions. Briefly, $25-\mu \mathrm{L}$ reactions were prepared, containing $12.5 \mu \mathrm{L}$ of $2 \times$ EmeraldAmp Max PCR Master Mix kit (Takara), $1 \mu \mathrm{L}$ of extracted DNA, 10 pmol of each primer, and ultrapure water (Takara). The amplification conditions were as follows: $94^{\circ} \mathrm{C}$ for $1 \mathrm{~min}$; 37 cycles of $94^{\circ} \mathrm{C}$ for $1 \mathrm{~min}, 55^{\circ} \mathrm{C}$ for $30 \mathrm{~s}$, and $72^{\circ} \mathrm{C}$ for $90 \mathrm{~s}$; and $72^{\circ} \mathrm{C}$ for $3.5 \mathrm{~min}$ for a final extension step. Negative controls (without DNA template) and a positive control (Staph. aureus ATCC 6538 template) were included in all PCR assays.

\section{Phenotypic Detection of Antimicrobial Resistance}

Antimicrobial susceptibility patterns for recovered Staph. aureus isolates were determined by the agar disc diffusion method according to the guidelines of the Clinical Laboratory Standard Institute (Bauer et al., 1966; CLSI, 2012). Penicillin G (10U), amoxicillin-clavulanic acid $(20 / 10 \mu \mathrm{g})$, tobramycin $(10 \mu \mathrm{g})$, tetracycline (30 $\mu \mathrm{g})$, gentamicin $(10 \mu \mathrm{g})$, azithromycin $(15 \mu \mathrm{g})$, oxacillin $(1 \mu \mathrm{g})$, streptomycin $(10 \mu \mathrm{g})$, cefoxitin $(30 \mu \mathrm{g})$, oxytetracycline $(30 \mu \mathrm{g})$, clindamycin $(2 \mu \mathrm{g})$, erythromycin $(15 \mu \mathrm{g})$, ampicillin $(10 \mu \mathrm{g})$, chloramphenicol $(30 \mu \mathrm{g})$, quinupristin-dalfopristin $(15 \mu \mathrm{g})$, ciprofloxacin $(5 \mu \mathrm{g})$, kanamycin $(30 \mu \mathrm{g})$, and trimethoprim-sulfamethoxazole $(1.25 / 23.75 \mu \mathrm{g})$ were used as antimicrobial agents (Oxoid, Basingstoke, UK). Staphylococcus aureus ATCC 6538 and Escherichia coli ATCC 25922 were used as quality controls in each run. The experiment was repeated twice.

\section{Antimicrobial Resistance Genes}

Antimicrobial resistance genes to penicillin (blaZ and mecA), cefoxitin ( $c f x A$ and $m e c A)$, aminoglycoside (aac6'-aph2", ant(6)-Ia, aph3'-IIIa), chloramphenicol $($ fexA and $\operatorname{cat} A)$, tetracycline $[\operatorname{tet}(\mathrm{K}), \operatorname{tet}(\mathrm{L}), \operatorname{tet}(\mathrm{M})$ and $\operatorname{tet}(\mathrm{O})]$, erythromycin $[\operatorname{erm}(\mathrm{A}), \operatorname{erm}(\mathrm{B}) \operatorname{erm}(\mathrm{C})$, $m s r(\mathrm{~A})$, and $m s r(\mathrm{~B})]$, streptomycin $[\operatorname{ant}(6)$-Ia], quinupristin-dalfopristin $[v g a(\mathrm{~A})$ and $v g a(\mathrm{~B})]$, and oxacillin $(m e c A)$ resistance genes, as well as the multidrugresistance gene ( $c f r)$ were tested by PCR in all Staph. aureus strains (Supplemental Table S1, https://doi .org/10.3168/jds.2017-13370).

\section{Detection of Virulence Determinants}

The genes encoding staphylococcal enterotoxins (sea, seb, sec, sed, see, seg, seh, sei, sek, sel, ser, ses, sej, and set), enterotoxin-like (selm, selo, selp, and selu), toxic-shock syndrome toxin (tst-1), exfoliative toxin genes (eta and etb), and Panton-Valentine leukocidin $(p v l)$ were detected by PCR. Amplified products were analyzed using $1.5 \%$ agarose gel electrophoresis and visualized by staining with SYBR Safe DNA Stain gel (Invitrogen, Carlsbad, CA). The information of all primers used for PCR is shown in Supplemental Table S1 (https://doi.org/10.3168/jds.2017-13370).

\section{RESULTS}

\section{Prevalence of Staph. aureus}

In the present study, 54 strains of Staph. aureus were isolated from raw milk, including 24 strains $(32 \%)$ in 75 Hohhot samples, 8 strains (26.7\%) in 30 Jinan samples, 11 strains $(27.5 \%)$ in 40 Harbin samples, and 11 strains $(22.0 \%)$ in 50 Beijing samples.

\section{Antimicrobial Susceptibility Testing}

The 54 isolates of Staph. aureus were tested for susceptibility to 18 antimicrobial agents by using the disc diffusion method. Antimicrobial resistance was most frequently observed to penicillin $\mathrm{G}(85.2 \%)$, followed by resistance to ampicillin (79.6\%), erythromycin (46.3\%), cefoxitin $(42.6 \%)$, clindamycin $(35.2 \%)$, azithromycin $(35.2 \%)$, ciprofloxacin $(29.6 \%)$, oxacillin $(29.6 \%)$, sulfamethoxazole-trimethoprim (20.4\%), kanamycin (14.8\%), oxytetracycline (14.8\%), tetracycline (13.0\%), gentamicin $(11.1 \%)$, streptomycin $(9.26 \%)$, chloramphenicol $(7.41 \%)$, tobramycin $(5.56 \%)$, quinupristindalfopristin (3.7\%), and amoxicillin-clavulanic acid (0\%) (Table 1). Among the 54 Staph. aureus isolates, resistance to $\beta$-lactams (47.4\%) was the most frequently observed, followed by resistance to macrolides $(40.8 \%)$ and lincomycin $(35.2 \%)$. Conversely, a low percentage of antimicrobial resistance was observed for chloramphenicol (7.41\%) and streptogramin (3.7\%). 
Table 1. Antibiotic resistance of Staphylococcus aureus strains isolated from raw milk in northern China

\begin{tabular}{llr}
\hline Antibiotic class & Antibiotic & Strains, no. (\%) \\
\hline$\beta$-Lactams & Penicillin G & $46(85.2)$ \\
& Ampicillin & $43(79.6)$ \\
& Cefoxitin & $23(42.6)$ \\
& Oxacillin & $16(29.6)$ \\
Macrolides & Amoxicillin-clavulanic acid & $0(0)$ \\
& Erythromycin & $25(46.3)$ \\
Lincomycin & Azithromycin & $19(35.2)$ \\
Quinolones & Clindamycin & $19(35.2)$ \\
Sulfonamides & Ciprofloxacin & $16(29.6)$ \\
Tetracyclines & Sulfamethoxazole-trimethoprim & $11(20.4)$ \\
& Oxytetracycline & $8(14.8)$ \\
Aminoglycosides & Tetracycline & $7(13.0)$ \\
& Kanamycin & $8(14.8)$ \\
& Gentamicin & $6(11.1)$ \\
Streptogramin & Streptomycin & $5(9.26)$ \\
Chloramphenicol & Tobramycin & $3(5.56)$ \\
Resistant to 1 antimicrobial agent & Quinupristin-dalfopristin & $2(3.7)$ \\
Resistant to 2 antimicrobial agents & Chloramphenicol & $4(7.41)$ \\
Multi-drug resistant & & $4(7.4)$ \\
\hline
\end{tabular}

Moreover, $72.2 \%$ of isolates showed resistance to 2 or more antibiotics. Two of the isolates were resistant to 12 of the 18 antibiotics tested, and 11 strains $(20.4 \%)$ were susceptible to all tested antimicrobial agents. Sixteen isolates $(29.6 \%)$ were identified as methicillinresistant strains by antimicrobial susceptibility (oxacillin resistance). All methicillin-resistant Staph. aureus (MRSA) showed resistance (100\%) to cefoxitin and penicillin.

\section{Screening of Antimicrobial Resistance Genes}

The results of antimicrobial resistance genes detection are presented in Table 2. All Staph. aureus isolates resistant to gentamicin, kanamycin, and oxacillin carried aac6'-aph2", ant(4')-Ia, and mecA genes, respectively. The blaZ, cfxA, and ant(4')-Ia genes were detected in $63,56.5$, and $66.7 \%$ of penicillin-resistant, cefoxitin-resistant, and tobramycin-resistant isolates, respectively. The tet $(\mathrm{K})$, tet $(\mathrm{M})$, and $\operatorname{tet}(\mathrm{L})$ genes were found alone or together with others in the following percentages of the isolates: $\operatorname{tet}(\mathrm{K})(14.3 \%), \operatorname{tet}(\mathrm{M})$ $(42.9 \%), \operatorname{tet}(\mathrm{K})+\operatorname{tet}(\mathrm{L})(28.6 \%)$, and $\operatorname{tet}(\mathrm{M})+\operatorname{tet}(\mathrm{L})$ $(14.3 \%)$. The tet $(\mathrm{L})$ gene was detected together with tet $(\mathrm{K})$ and tet $(\mathrm{M})$ in the same isolates. No tetracyclineresistant isolates harbored the $\operatorname{tet}(\mathrm{O})$ gene. Additionally, 2 tet $(\mathrm{M})$-positive strains carried a $\operatorname{Tn} 916-\operatorname{Tn} 1545$ transposon gene. The erythromycin-resistant isolates (n $=25$ ) harbored $\operatorname{erm}(\mathrm{B})$ (3 isolates, 12\%), erm (C) (4 isolates, 16\%), $m s r(\mathrm{~A})(1$ isolate, $4 \%), \operatorname{erm}(\mathrm{B})$ and $\operatorname{erm}(\mathrm{C})$ (3 isolates, 12\%), $\operatorname{erm}(\mathrm{C})$ and $\operatorname{erm}(\mathrm{A})$ (1 isolate, $4 \%)$, $\operatorname{erm}(\mathrm{C})$ and $m s r(\mathrm{~A})(2$ isolates, $8 \%)$, and $\operatorname{erm}(\mathrm{C})$ and $m s r(B)$ genes (1 isolate, $4 \%$ ). However, fexA and catA genes were not detected in chloramphenicol-resistant strains. The ant(6)-Ia gene was not detected in streptomycin-resistant strains; and $v g a(\mathrm{~A})$ and $v g a(\mathrm{~B})$ genes were not detected in quinupristin-dalfopristin-resistant strains. Furthermore, the correlations between resistant phenotypes and genotypes for tetracycline, gentamicin, kanamycin, and oxacillin were $100 \%$.

\section{Distribution of Virulence Genes}

As shown in Table 3 , the most predominant toxin genes were $\sec (12 / 54,22.2 \%)$, followed by sea $(8 / 54$, $14.8 \%)$, pvl $(8 / 54,14.8 \%)$, tst $(8 / 54,14.8 \%)$, sej $(7 / 54$, $13.0 \%)$, selp $(6 / 54,11.1 \%)$, ses $(5 / 54,9.3 \%)$, seg $(5 / 54$, $9.3 \%)$, sei $(4 / 54,7.4 \%)$, sed $(4 / 54,7.4 \%)$, seb $(3 / 54$, $5.6 \%)$, ser $(1 / 54,1.9 \%)$, eta $(1 / 54,1.9 \%)$, see $(1 / 54$, $1.9 \%)$, and set $(1 / 54,1.9 \%)$. The seh, sek, sel, selm, selo, selu, and etb genes were not detected in the Staph. aureus isolates.

As shown in Table 4, $59.2 \%$ of the strains $(32 / 54)$ harbored one or more virulence genes, and $40.7 \%$ of the strains $(22 / 54)$ did not detect any of the above virulence genes. Among the 32 Staph. aureus strains, one strain harbored 6 virulence genes together: seg, sec, tst, sea, selp, and pvl. Three isolates harbored 4 virulence genes with 2 different gene patterns, and the combination of seg, sec, tst, and sea was the dominant gene pattern. Eight isolates harbored 3 virulence genes with 8 different gene patterns. Nine isolates harbored 2 virulence genes with 7 different gene patterns, and the combinations of sei and pvl or sei and sej was the dominant gene pattern. Eleven isolates possessed one virulence gene with 7 different gene patterns. 
Table 2. Antimicrobial resistance genes identified in Staphylococcus aureus strains isolated from raw milk samples from northern China

\begin{tabular}{|c|c|c|}
\hline Antibiotic & Resistance gene & $\begin{array}{c}\text { No. }(\%) \text { of positive } \\
\text { strains }\end{array}$ \\
\hline \multirow[t]{2}{*}{ Penicillin G } & blacZ & $29(63)$ \\
\hline & mecA & 0 \\
\hline \multirow[t]{2}{*}{ Cefoxitin } & $c f x A$ & $13(56.5)$ \\
\hline & mecA & 0 \\
\hline Tobramycin & $\operatorname{ant}\left(4^{\prime}\right)-\mathrm{Ia}$ & $2(66.7)$ \\
\hline Gentamicin & aac6'-aph2" & $6(100)$ \\
\hline \multirow[t]{2}{*}{ Chloramphenicol } & $\operatorname{fexA}$ & 0 \\
\hline & catA & 0 \\
\hline \multirow[t]{5}{*}{ Tetracycline } & $\operatorname{tet}(\mathrm{K})$ & $1(14.3)$ \\
\hline & tet $(\mathrm{K})+\operatorname{tet}(\mathrm{L})$ & $2(28.6)$ \\
\hline & $\operatorname{tet}(\mathrm{M})$ & $3(42.9)$ \\
\hline & $\operatorname{tet}(\mathrm{M})+\operatorname{tet}(\mathrm{L})$ & $1(14.3)$ \\
\hline & $\operatorname{tet}(\mathrm{O})$ & 0 \\
\hline \multirow[t]{8}{*}{ Erythromycin } & erm(B) & $3(12)$ \\
\hline & $\operatorname{erm}(\mathrm{B})+\operatorname{erm}(\mathrm{C})$ & $3(12)$ \\
\hline & $\operatorname{erm}(\mathrm{C})$ & $4(16)$ \\
\hline & $\operatorname{erm}(\mathrm{C})+\operatorname{erm}(\mathrm{A})$ & $1(4)$ \\
\hline & $\operatorname{erm}(\mathrm{C})+m s r(\mathrm{~A})$ & $2(8)$ \\
\hline & $\operatorname{erm}(\mathrm{C})+m s r(\mathrm{~B})$ & $1(4)$ \\
\hline & $m s r(\mathrm{~A})$ & $1(4)$ \\
\hline & $\operatorname{erm}(\mathrm{A}), \operatorname{msr}(\mathrm{B})$, or both & 0 \\
\hline Kanamycin & $\operatorname{ant}\left(4^{\prime}\right)$-Ia & $8(100)$ \\
\hline Oxacillin & mecA & $16(100)$ \\
\hline Streptomycin & ant (6)-Ia & 0 \\
\hline Quinupristin-dalfopristin & $v g a(\mathrm{~A}), v g a(\mathrm{~B})$, or both & 0 \\
\hline
\end{tabular}

\section{DISCUSSION}

In the present study, 25.8\% (54/195) of raw milk samples were positive for Staph. aureus. The value is significantly lower than in previous reports, which indicated that the occurrence rate of Staph. aureus in raw milk was $83 \%$ in Turkey (Bartolomeoli et al., 2009), $66.7 \%$ in Malaysia (Andre et al., 2008), 56\% in Brazil (Gundogan and Avci, 2014), and $41.0 \%$ in Italy (Traversa et al., 2015). In contrast, a much lower occurrence rate $(12.4 \%)$ of Staph. aureus was found in raw milk in
Iran (Jamali et al., 2015). Overall, the results of our current study indicate that Staph. aureus is common in raw milk collected from dairy herds throughout northern China. Major sources of Staph. aureus in raw milk might include infected cows and inappropriate hygiene conditions (Jamali et al., 2015). Further research is ongoing and will explore methods of controlling Staph. aureus occurrence in raw milk.

In our analysis, $72.2 \%$ of isolates showed resistance to 2 or more antibiotics, and $61.1 \%$ of Staph. aureus isolates showed multidrug resistance (MDR), which

Table 3. Virulence genes identified in Staphylococcus aureus strains isolated from raw milk samples from northern China $(\mathrm{n}=54)$

\begin{tabular}{lllc}
\hline Class of toxin & Type of toxin & Gene & $\begin{array}{c}\text { No. (\%) of positive } \\
\text { strains }\end{array}$ \\
\hline Enterotoxins & Enterotoxin A & sea & $8(14.8)$ \\
& Enterotoxin B & seb & $3(5.6)$ \\
& Enterotoxin C & sec & $12(22.2)$ \\
& Enterotoxin D & sed & $4(7.4)$ \\
& Enterotoxin E & see & $1(1.9)$ \\
& Enterotoxin G & seg & $5(9.3)$ \\
& Enterotoxin I & sei & $4(7.4)$ \\
& Enterotoxin R & ser & $1(1.9)$ \\
Enterotoxin-like & Enterotoxin S & ses & set \\
Toxic-shock syndrome toxin & Enterotoxin T & sej & $7(1.9)$ \\
Exfoliative toxins & Enterotoxin J & selp & $6(11.1)$ \\
Panton-Valentine leukocidin & Enterotoxin-like protein P & tst-1 & $8(14.8)$ \\
\hline
\end{tabular}


was much higher than reported in other studies. Other researchers have reported lower rates of MDR Staph. aureus (Haran et al., 2012; Jamali et al., 2015). The high prevalence of drug-resistant Staph. aureus from raw milk - the raw material for dairy products - should be considered a potential risk to human health in northern China. Moreover, we investigated antibiotic use for mastitis in northern China in our previous survey, and found that 6 antibiotics (penicillin, ampicillin, ciprofloxacin, sulfamethoxazole-trimethoprim, gentamicin, and streptomycin) are commonly used in dairy mastitis therapy (data not shown). In the current study, most of the Staph. aureus strains showed a high percentage of antimicrobial resistance to penicillin, ampicillin, ciprofloxacin, and sulfamethoxazole-trimethoprim. The results indicated a correlation between antibiotic use and antimicrobial resistance. Similar findings were reported by Saini et al. (2012), who found that herd-level use of certain antimicrobials administered for mastitis treatment was positively associated with antimicrobial resistance in isolates from a clinical mastitis sample. Data on antibiotic susceptibility of Staph. aureus can be helpful in choosing the most suitable antibiotic for mastitis treatment (Wang et al., 2016). Based on the high percentage of resistance to penicillin and ampicillin, these antibiotics should be used with caution for mastitis caused by Staph. aureus in dairy herds in northern China.
Methicillin-resistant Staph. aureus is an emerging pathogen in livestock animals that is readily transferable to humans that are in contact with livestock. In this study, 16 isolates (29.6\%) were identified as MRSA by antimicrobial susceptibility, and all MRSA isolates showed resistance to cefoxitin and penicillin, which is similar to findings of several prior studies (Bhargava and Zhang, 2012; Chajecka-Wierzchowska et al., 2015). The MRSA resistance was caused by the expression of a modified penicillin-binding protein (PBP), named PBP2A, with reduced affinity for $\beta$-lactam antimicrobial agents. For MRSA, $\beta$-lactams cannot bind to native PBP2A, so synthesis of peptidoglycan and bacterial growth occur normally (Diaz et al., 2016).

Tetracylines are broad-spectrum antimicrobial agents frequently used in the treatment of infections in cattle (Chajecka-Wierzchowska et al., 2016). In our study, $13.9 \%$ of Staph. aureus isolates showed resistance to tetracylines. The high prevalence of resistance to tetracycline has been reported previously among Staph. aureus isolates from different sources (Andre et al., 2008; Gundogan and Avci, 2014; Jamali et al., 2015). Moreover, tetracycline resistance can be conferred by genes encoding efflux proteins TetK and TetL or ribosomal protection proteins TetM, TetO, and TetS (Huys et al., 2004). In our study, all the tetracycline-resistant isolates harbored at least one tetracycline resistance determinant, of which tet( $\mathrm{M})$ was most frequent. These

Table 4. Multiple gene patterns identified in Staphylococcus aureus strains isolated from raw milk samples from northern China

\begin{tabular}{|c|c|c|c|}
\hline No. of toxin genes & Genotypes & No. of isolates & Total \\
\hline 6 & seg, sec, tst, sea, selp, pvl & 1 & 1 \\
\hline \multirow[t]{2}{*}{4} & sec, tst, sea, pvl & 1 & 3 \\
\hline & seg, sec, tst, sea & 2 & \\
\hline \multirow[t]{8}{*}{3} & sec, eta, pvl & 1 & 8 \\
\hline & sed, sei, pvl & 1 & \\
\hline & sed, seg, sej & 1 & \\
\hline & see, sec, sea & 1 & \\
\hline & seg, sec, selp & 1 & \\
\hline & sej, sec, selp & 1 & \\
\hline & sej, selp, sea & 1 & \\
\hline & sec, tst, sea & 1 & \\
\hline \multirow[t]{7}{*}{2} & sea, sei & 1 & 9 \\
\hline & sea, sed & 1 & \\
\hline & seg, tst & 1 & \\
\hline & $s e i, s e j$ & 2 & \\
\hline & sei, pvl & 2 & \\
\hline & $\mathrm{sei}, \mathrm{sec}$ & 1 & \\
\hline & sei, tst & 1 & \\
\hline \multirow[t]{7}{*}{1} & $\mathrm{sec}$ & 1 & 11 \\
\hline & sed & 2 & \\
\hline & seg & 1 & \\
\hline & sej & 1 & \\
\hline & ser & 2 & \\
\hline & $s e b$ & 3 & \\
\hline & $p v l$ & 1 & \\
\hline
\end{tabular}


results are in agreement with the findings of Bhargava and Zhang (2012), who detected tet(M) in $64.3 \%$ of investigated strains. In the current study, tet( $\mathrm{M})$-positive isolates carried the transposon and tet $(\mathrm{M})$ was the most prevalent tet gene detected among the tetracyclineresistant Staph. aureus isolates. Several studies have shown that the spread of resistance to antimicrobial is largely due to the acquisition of plasmids or transposons (Lopatkin et al., 2016; Pehrsson et al., 2016).

In this study, the correlation between resistant phenotypes and genotypes for tetracycline, gentamicin, kanamycin, and oxacillin was $100 \%$. Genotypic prediction of resistance relies on highly curated databases of known resistance determinants and cannot identify new mechanisms. Therefore, testing phenotypic susceptibility is still necessary to fully account for resistance and predict new mechanisms of resistance (Zhao et al., 2015). Knowing which antimicrobial resistance genes are present in bacterial populations is critical to developing new strategies to combat antimicrobial resistance, including improving antimicrobial resistance and implementing surveillance programs for foodborne diseases.

Another important factor in the pathogenesis of Staph. aureus infections is virulence. Once enterotoxins are produced, they generally retain their biological activity even after heat treatment (Cavicchioli et al., 2015). In the present study, 19 staphylococcal enterotoxin genes were tested, and $60.3 \%$ of Staph. aureus isolates harbored one or more of these virulence genes. The enterotoxin gene distribution in Staph. aureus isolates from raw milk could provide epidemiological information for public health and food safety. The sec, sea, pvl, and tst genes were frequently detected in isolates from raw milk in our study. The most frequently reported virulence gene in Staph. aureus from goat milk is the sec gene (Cavicchioli et al., 2015); tst and sec are usually detected together from goat and ovine milk (Xing et al., 2016); and pvl is usually detected in Staph. aureus from raw milk. The pvl gene plays an important role in pathogenesis with a strong ability to stimulate cytolysis of neutrophils, apoptosis, and production of pro-inflammatory molecules (Liu, 2009). This suggests that attention should be paid not only to classical enterotoxins in raw milk and other dairy products, but also to other virulence factors detected among pathogenic staphylococci.

\section{CONCLUSIONS}

This study assessed the antimicrobial resistance of Staph. aureus strains isolated from raw milk in northern China. Our data indicate that Staph. aureus is prevalent in raw milk from herds in the northern region. The detected Staph. aureus strains exhibited a high percentage of antimicrobial resistance and carried multiple virulence genes. Therefore, it is important to monitor the use of antimicrobial agents and the potential transfer of antimicrobial resistance genes in northern China. Penicillin G and ampicillin for mastitis caused by Staph. aureus should be used with caution in dairy herds in northern China. Further studies should be carried out to evaluate the possibility of acquiring, transferring, and transmitting antimicrobial resistance genes among Staph. aureus.

\section{ACKNOWLEDGMENTS}

This research was supported by Project of Risk Assessment on raw milk (GJFP2016008, Beijing, China) Special Fund for Agro-scientific Research in the Public Interest (201403071, Beijing, China), The Agricultural Science and Technology Innovation Program (ASTIP-IAS12, Beijing, China) Fundamental Research Funds for the Central Non-profit Research Institution (2015ywf-zd-3, Beijing, China), and Modern AgroIndustry Technology Research System of the PR China (CARS-37, Beijing, China).

\section{REFERENCES}

Andre, M. C. D. P. B., M. R. H. Campos, L. J. Borges, A. Kipnis, F. C. Pimenta, and A. I. B. Serafini. 2008. Comparison of Staphylococcus aureus isolated from food handlers, raw bovine milk, and minas frescal cheese by antibiotics and pulsed-field gel electrophoresis following sma digestion. Food Contr. 19:200-207.

Bartolomeoli, I., M. Maifreni, F. Frigo, G. Urli, and M. Marino. 2009. Occurrence and characterization of Staphylococcus aureus isolated from raw milk for cheese making. Int. J. Dairy Technol. 62:366371.

Bauer, A. W., W. M. Kirby, J. C. Sherris, and M. Turck. 1966. Antibiotic susceptibility testing by a standardized single disk method. Am. J. Clin. Pathol. 45:493-496.

Baym, M., L. K. Stone, and R. Kishony. 2016. Multidrug evolutionary strategies to reverse antibiotic resistance. Science 351:aad3292.

Bhargava, K., and Y. Zhang. 2012. Multidrug-resistant coagulase-negative staphylococci in food animals. J. Appl. Microbiol. 113:10271036.

Cavicchioli, V. Q., T. M. Scatamburlo, A. K. Yamazi, F. A. Pieri, and L. A. Nero. 2015. Occurrence of Salmonella, Listeria monocytogenes and enterotoxigenic Staphylococcus in goat milk from small and medium-sized farms located in Minas Gerais State, Brazil. J. Dairy Sci. 98:8386-8390.

Chajecka-Wierzchowska, W., A. Zadernowska, and L. Laniewska-Trokenheim. 2016. Virulence factors, antimicrobial resistance and biofilm formation in Enterococcus spp. isolated from retail shrimps. Food Sci. Technol. 69:117-122.

Chajecka-Wierzchowska, W., A. Zadernowska, B. Nalepa, M. Sierpinska, and L. Laniewska-Trokenheim. 2015. Coagulase-negative staphylococci (CoNS) isolated from ready-to-eat food of animal origin-phenotypic and genotypic antibiotic resistance. Food Microbiol. 46:222-226.

CLSI. 2012. Performance standards for antimicrobial susceptibility testing. Document M100-S22. Clinical and Laboratory Standards Institute (CLSI), Wayne, PA.

de Freitas Guimarães, F., D. B. Nobrega, V. B. Richini-Pereira, P. M. Marson, and H. Langoni. 2013. Enterotoxin genes in coagulase- 
negative and coagulase-positive staphylococcus isolated from bovine milk. J. Dairy Sci. 96:2866-2872.

Diaz, R., E. Ramalheira, V. Afreixo, and B. Gago. 2016. Methicillinresistant Staphylococcus aureus carrying the new mecC gene- $\mathrm{A}$ meta-analysis. Diagn. Microbiol. Infect. Dis. 84:135-140.

Gomes, F., and M. Henriques. 2016. Control of bovine mastitis: Old and recent therapeutic approaches. Curr. Microbiol. 72:377-382.

Gundogan, N., and E. Avci. 2014. Occurrence and antibiotic resistance of Escherichia coli, Staphylococcus aureus and Bacillus cereus in raw milk and dairy products in Turkey. Int. J. Dairy Technol. $67: 562-569$.

Haran, K. P., S. M. Godden, D. Boxrud, S. Jawahir, J. B. Bender, and S. Sreevatsan. 2012. Prevalence and characterization of Staphylococcus aureus, including methicillin-resistant Staphylococcus aureus, isolated from bulk tank milk from Minnesota dairy farms. J. Clin. Microbiol. 50:688-695.

Huys, G., K. D'Haene, J. M. Collard, and J. Swings. 2004. Prevalence and molecular characterization of tetracycline resistance in Enterococcus isolates from food. Appl. Environ. Microbiol. 70:1555-1562.

Jamali, H., M. Paydar, B. Radmehr, S. Ismail, and A. Dadrasnia. 2015. Prevalence and antimicrobial resistance of Staphylococcus aureus isolated from raw milk and dairy products. Food Contr. $54: 383-388$

Kot, B., P. Szweda, A. Frankowska-Maciejewska, M. Piechota, and K. Wolska. 2016. Virulence gene profiles in Staphylococcus aureus isolated from cows with subclinical mastitis in eastern Poland. J. Dairy Res. 83:228-235.

Liu, G. Y. 2009. Molecular pathogenesis of Staphylococcus aureus infection. Pediatr. Res. 65:71R-77R.

Lopatkin, A. J., S. Q. Huang, R. Smith, J. K. Srimani, T. Sysoeva, S. Bewick, D. K. Karig, and L. C. You. 2016. Antibiotics as a selective driver for conjugation dynamics. Nat. Microbiol. 1:16044.

Mistry, H., P. Sharma, S. Mahato, R. Saravanan, P. A. Kumar, and V. Bhandari. 2016. Prevalence and characterization of oxacillin susceptible mecA-positive clinical isolates of Staphylococcus aureus causing bovine mastitis in India. PLoS One 11:e162256.

Pehrsson, E. C., P. Tsukayama, S. Patel, M. Mejia-Bautista, G. SosaSoto, K. M. Navarrete, M. Calderon, L. Cabrera, W. Hoyos-Arango, M. T. Bertoli, D. E. Berg, R. H. Gilman, and G. Dantas. 2016. Interconnected microbiomes and resistomes in low-income human habitats. Nature 533:212-216.
Rajagopal, M., M. J. Martin, M. Santiago, W. Lee, V. N. Kos, T. Meredith, M. S. Gilmore, and S. Walker. 2016. Multidrug intrinsic resistance factors in Staphylococcus aureus identified by profiling fitness within high-diversity transposon libraries. MBio 7:e00950-16.

Ruegg, P. L., L. Oliveira, W. Jin, and O. Okwumabua. 2015. Phenotypic antimicrobial susceptibility and occurrence of selected resistance genes in gram-positive mastitis pathogens isolated from Wisconsin dairy cows. J. Dairy Sci. 98:4521-4534.

Saini, V., J. T. McClure, D. T. Scholl, T. J. DeVries, and H. W. Barkema. 2012. Herd-level association between antimicrobial use and antimicrobial resistance in bovine mastitis Staphylococcus aureus isolates on Canadian dairy farms. J. Dairy Sci. 95:1921-1929.

Stapels, D. A. C., K. X. Ramyar, M. Bischoff, M. van Kockritz-Blickwede, F. J. Milder, M. Ruyken, J. Eisenbeis, W. J. McWhorter M. Herrmann, K. P. M. van Kessel, B. V. Geisbrecht, and S. H. M. Rooijakkers. 2014. Staphylococcus aureus secretes a unique class of neutrophil serine protease inhibitors. Proc. Natl. Acad. Sci. USA 111:13187-13192.

Traversa, A., G. R. Gariano, S. Gallina, D. M. Bianchi, R. Orusa, L. Domenis, P. Cavallerio, L. Fossati, R. Serra, and L. Decastelli. 2015. Methicillin resistance in Staphylococcus aureus strains isolated from food and wild animal carcasses in Italy. Food Microbiol. $52: 154-158$

Wang, D., L. M. Zhang, X. Z. Zhou, Y. L. He, C. H. Yong, M. L. Shen, O. Szenci, and B. Han. 2016. Antimicrobial susceptibility, virulence genes, and randomly amplified polymorphic DNA analysis of Staphylococcus aureus recovered from bovine mastitis in Ningxia, China. J. Dairy Sci. 99:9560-9569.

Xing, X. M., Y. Zhang, Q. Wu, X. Wang, W. P. Ge, and C. M. Wu. 2016. Prevalence and characterization of Staphylococcus aureus isolated from goat milk powder processing plants. Food Contr. 59:644-650.

Zhang, L. L., Y. C. Li, H. D. Bao, R. C. Wei, Y. Zhou, H. Zhang, and R. Wang. 2016. Population structure and antimicrobial profile of Staphylococcus aureus associated with bovine mastitis in China. Microb. Pathog. 97:103-109.

Zhao, S., G. H. Tyson, Y. Chen, C. Li, S. Mukherjee, S. Young, C. Lam, J. P. Folster, J. M. Whichard, and P. F. McDermott. 2015. Whole genome sequencing analysis accurately predicts antimicrobial resistance phenotypes in Campylobacter. Appl. Environ. Microbiol. 82:459-466. 